\title{
Mineralocorticoid receptor activation in obesity hypertension
}

\author{
Miki Nagase $^{1,2}$ and Toshiro Fujita ${ }^{1}$
}

Obesity hypertension and metabolic syndrome have become major public health concerns. Nowadays, aldosterone is recognized as an important mediator of cardiovascular and renal damage. In the kidney, aldosterone injures glomerular visceral epithelial cells (podocytes), the final filtration barrier to plasma macromolecules, leading to proteinuria and glomerulosclerosis. Mineralocorticoid receptor (MR) antagonists effectively ameliorate proteinuria in patients or in animal models of hypertension, diabetes mellitus and chronic kidney disease (CKD), as well as in patients who experience 'aldosterone breakthrough.' Recently, clinical and experimental studies have shown that plasma aldosterone concentration is associated with obesity hypertension and metabolic syndrome. We showed that spontaneously hypertensive rats (SHR)/cp, an experimental model of obesity hypertension and metabolic syndrome, are prone to glomerular podocyte injury, proteinuria and left ventricular diastolic dysfunction, especially when the animals are fed a high-salt diet. Inappropriate activation of the aldosterone/MR system underlies the renal and cardiac injuries. Adipocyte-derived aldosterone-releasing factors (ARFs), although still unidentified, may account for aldosterone excess and the resultant target organ complication in SHR/cp. On the other hand, recent studies have shown that MR activation triggers target organ disease even in normal or low aldosterone states. We identified a small GTP (guanosine triphosphate)-binding protein, Rac1, as a novel activator of MR, and showed that this ligand-independent MR activation by Rac1 contributes to the nephropathy of several CKD models. We expect that ARFs and Rac1 can be novel therapeutic targets for metabolic syndrome and CKD. Future large-scale clinical trials are awaited to prove the efficacy of MR blockade in patients with obesity hypertension and metabolic syndrome.

Hypertension Research (2009) 32, 649-657; doi:10.1038/hr.2009.86; published online 12 June 2009

Keywords: aldosterone; glomerular podocyte injury; proteinuria; Rac1 GTPase; salt

\section{INTRODUCTION}

The modern sedentary lifestyle, unhealthy food with too much fat and salt, physical inactivity and psychological stress have led to a global epidemic of obesity in the last few decades. ${ }^{1,2}$ In particular, obesity hypertension and metabolic syndrome have become major public health concerns. ${ }^{3,4}$ According to the 2006 National Health and Nutrition Survey in Japan, one out of two men and one out of five women aged between 40 and 74 years are suffering from metabolic syndrome or are sufferers-to-be.

Recently, the nuclear receptor superfamily has been postulated as key molecules in metabolic syndrome. ${ }^{5-7}$ The nuclear receptors are ligandactivated transcription factors whose activity is regulated by small lipophilic molecules that include steroid hormones, fat-soluble vitamins, thyroid hormone, retinoids and dietary lipids, and control genes involved in glucose, lipid and energy metabolism. ${ }^{8}$ The family also includes orphan nuclear receptors, such as peroxisome proliferatoractivated receptor (PPAR) $-\alpha, \gamma, \delta$, liver $\mathrm{X}$ receptor and farnesoid X receptor. Indeed, genetically engineered mice of estrogen receptor, ${ }^{9}$ androgen receptor, ${ }^{10}$ glucocorticoid activating enzyme $11 \beta$-hydroxysteroid dehydrogenase type 1 (11 $\beta$-HSD 1$),{ }^{11}$ PPAR- $\gamma^{12}$ and PPAR- $\delta^{13}$ were reported to develop visceral obesity and metabolic syndrome. On the other hand, the renin-angiotensin-aldosterone system (RAAS) is also implicated in the pathogenesis of metabolic syndrome. ${ }^{14,15}$ Aldosterone is a component of the RAAS and its receptor mineralocorticoid receptor (MR) belongs to the nuclear receptor superfamily. Recent studies have suggested an etiological role for aldosterone/MR in the development of metabolic syndrome. On the other hand, the aldosterone/MR system also has a critical role in the progression of target organ damage in metabolic syndrome. We have shown that renal and cardiac injuries in an experimental model of metabolic syndrome are strongly dependent on the activation of the aldosterone/MR system. ${ }^{16-18}$ In addition, MR activation causes target organ damage even in normal or low aldosterone states. ${ }^{19,20}$ We identified a small guanosine triphosphate (GTP)-binding protein, Rac1, as a novel mediator of ligand-independent MR activation, and cross-talk between Racl and MR contributes to the nephropathy of several chronic kidney disease (CKD) models. ${ }^{21}$

${ }^{1}$ Department of Nephrology and Endocrinology, University of Tokyo Graduate School of Medicine, Bunkyo-ku, Tokyo, Japan and ${ }^{2}$ Division of Chronic Kidney Disease, University of Tokyo Graduate School of Medicine, Tokyo, Japan

Correspondence: Professor T Fujita, Department of Nephrology and Endocrinology, University of Tokyo Graduate School of Medicine, 7-3-1 Hongo, Bunkyo-ku, Tokyo 113-8655, Japan.

E-mail: fujita-dis@h.u-tokyo.ac.jp

Received 13 May 2009; accepted 13 May 2009; published online 12 June 2009 
The human MR gene has two alternative promoters, P1 and P2. The transgenic expression of SV40 large $\mathrm{T}$ antigen driven by the P1 promoter resulted in lethal hibernomas, unraveling a new functional link between aldosterone and energy homeostasis in brown adipose tissues. $^{22,23}$ Overexpression of human MR under the control of the P1 promoter resulted in abnormal urinary electrolyte excretion and dilated cardiomyopathy-like cardiac lesion, supporting the role in cardiovascular disease (CVD) and CKD. ${ }^{24}$

In this review, we first provide a general overview of obesity and hypertension and then focus on the link between aldosterone/MR and metabolic syndrome. Finally, we introduce our recent findings on the roles of aldosterone-dependent and aldosterone-independent MR activation in target organ complication associated with metabolic syndrome.

\section{OBESITY AND HYPERTENSION}

Both genetic and environmental factors contribute to the development of hypertension. Recent genome-wide association studies of BP and hypertension identified several loci associated with hypertension. ${ }^{25,26}$ On the other hand, obesity is shown to be one of the major environmental factors to increase the risk of hypertension.

Obesity, especially visceral obesity, is closely related to hypertension. ${ }^{27-30}$ Blood pressure (BP) increases $\sim 4.5 \mathrm{~mm} \mathrm{Hg}$ for every $10 \mathrm{lb}$ (4.5 kg) weight gain. ${ }^{31}$ During a 4 -year follow-up, $5 \%$ weight gain was associated with $20-30 \%$ increased odds of hypertension. ${ }^{29}$ According to the Framingham Heart Study, $65-75 \%$ of the risk for hypertension is attributed to excess weight. ${ }^{28}$ Both obesity and hypertension convey increased risk for CVD. In addition, visceral obesity and hypertension often cluster with insulin resistance, dyslipidemia, inflammation and prothrombotic states. ${ }^{3,32}$ This risk-factor clustering condition, known as metabolic syndrome, is a highly predisposing condition for target organ injury. ${ }^{33,34}$ Furthermore, high salt intake increases BP and worsens cardiovascular and renal outcomes in patients with obesity and metabolic syndrome. ${ }^{35-38}$
Several candidate chromosomal loci or single nucleotide polymorphisms (SNPs) are postulated. For example, a whole-genome scan suggests a locus at 1 p36 for obesity hypertension. ${ }^{39}$ Genetic studies in humans suggest the association of obesity hypertension with variants of several genes, including tumor necrosis factor- $\alpha$ (TNF$\alpha),{ }^{40}$ glucocorticoid receptor, ${ }^{41}$ CYP $11 B 22^{42}$ and serum and glucocorticoid-regulated kinase (Sgk)1. ${ }^{43}$ Diseases of civilization, including obesity and hypertension, may result from the mismatch between contemporary environment and 'energy-thrifty genotype' of genes, which helped our ancestors survive occasional famines. ${ }^{44,45}$ According to the 'fetal programming of adult disease' hypothesis proposed by Barker et al., ${ }^{46}$ obesity and metabolic syndrome in adulthood originate from malnutrition of the fetus during intrauterine life, which leads to functional and structural adaptive processes for its survival and a compensatory catch-up growth.

\section{Mechanisms of obesity hypertension}

Obese subjects have increased cardiac output and plasma volume as well as reduced peripheral vascular resistance. Enhanced renal tubular sodium reabsorption has a central role in the pathogenesis of obesity hypertension. According to Guyton's theory, ${ }^{47}$ sodium retention impairs pressure natriuresis; higher pressure is necessary for maintaining a sodium balance, resulting in hypertension (right shift in the pressure-natriuresis curve). Multiple factors are postulated to contribute to the enhanced sodium reabsorption, as described below (Figure 1). ${ }^{48-50}$

\section{Sympathetic nervous system}

Renal sympathetic overactivity increases sodium reabsorption and vasoconstriction. Leptin, an adipokine secreted in proportion to adiposity, is believed to be an important mediator linking obesity, renal sympathetic activation and hypertension. Leptin acts on the ventromedial and dorsomedial hypothalamic nuclei and regulates

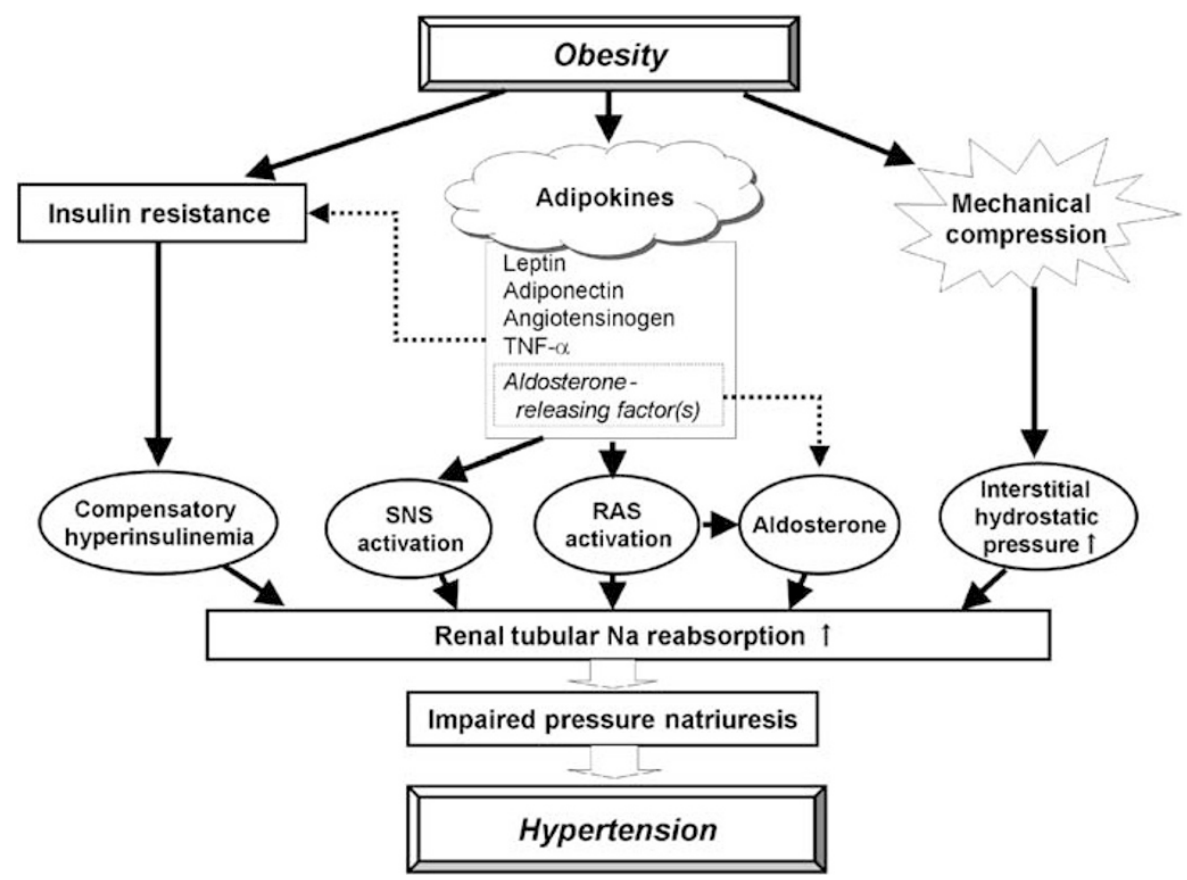

Figure 1 Mechanisms of obesity hypertension. Activation of the sympathetic nervous system (SNS), renin-angiotensin system (RAS), aldosterone, hyperinsulinemia and mechanical compression of the kidney cause increased renal tubular sodium reabsorption and hypertension. Adipocyte-derived factors, such as leptin, angiotensinogen and aldosterone-releasing factors, are supposed to have important roles. TNF- $\alpha$, tumor necrosis factor- $\alpha$. 
energy homeostasis by reducing appetite and increasing energy expenditure. It also modulates renal sympathetic outflow through the melanocortin system. Obesity may cause 'selective leptin resistance, whereby the sympathetic nervous system (SNS) responses to leptin are maintained, whereas its anorexic effect is blunted. ${ }^{51}$ Renal sympathetic activation is also caused by insulin, non-esterified fatty acids, angiotensin II and aldosterone.

\section{Renin-angiotensin system}

Despite marked sodium retention, obesity hypertension is associated with activation of the renin-angiotensin system (RAS). The increased renin secretion may be caused by the increased sympathetic stimulation. Alternatively, angiotensinogen produced by the adipose tissue may contribute to the high circulating angiotensinogen levels in obesity hypertension. ${ }^{15}$ Overexpression of $11 \beta$-HSD 1 in the adipose tissue results in visceral obesity and metabolic syndrome. The mice had increased angiotensinogen in the plasma and in the adipose tissue, and hypertension was abolished by angiotensin II type 1 receptor antagonist $(\mathrm{ARB}) .{ }^{52}$

\section{Aldosterone}

Details are described in the next section.

\section{Hyperinsulinemia}

Obese subjects are characterized by hyperinsulinemia and insulin resistance. Hyperinsulinemia could increase sympathetic activity and sodium reabsorption, modify ion transport and stimulate proliferation of smooth muscle cells.

Similar to the case of leptin, insulin actions are blunted in the muscle and adipose tissues, whereas renal action is preserved and facilitated by hyperinsulinemia, resulting in enhanced sodium absorption. The former actions are mediated by insulin receptor substrates (IRS)-1, and the latter by IRS-2. ${ }^{53}$

\section{Renal mechanical compression}

Visceral fat mass may compress the kidney and increase tubular reabsorption. Changes in the renal medullary histology may increase interstitial hydrostatic pressure, compress the thin loops of Henle and vasa recta and enhance tubular reabsorption.

\section{ALDOSTERONE AND OBESITY HYPERTENSION/METABOLIC SYNDROME}

Aldosterone excess has been implicated in obesity-related disorders.

In 1981, Tuck et al. ${ }^{54}$ first suggested the involvement of aldosterone in the pathogenesis of obesity-associated hypertension. They indicated that weight reduction decreased plasma renin activity and aldosterone concentration, along with BP in obese patients. A recent study by Engeli et al. ${ }^{55}$ showed that in menopausal women, the obese group had higher plasma aldosterone compared with the lean group (62 \pm 25 vs. $\left.38 \pm 17 \mathrm{ngl}^{-1}\right)$, and that weight reduction $(-5 \%)$ by caloric restriction was accompanied by a reduction in $\mathrm{BP}(-7 \mathrm{~mm} \mathrm{Hg})$ and plasma aldosterone $(-31 \%)$. Similarly, patients with visceral-type morbid obesity (body mass index $49.0 \pm 3.5 \mathrm{~kg} \mathrm{~m}^{-2}$ ) had increased plasma aldosterone concentration (1070 $\pm 137 \mathrm{pM}$, normal: $190-932 \mathrm{pm})$, which was significantly reduced $(699 \pm 90 \mathrm{pM})$ after the correction of body mass index $\left(27.7 \pm 2.0 \mathrm{~kg} \mathrm{~m}^{-2}\right)$ by gastric bypass surgery. Morbidly obese patients of subcutaneous type had lower plasma aldosterone levels $(810 \pm 103 \mathrm{pm}) .{ }^{56}$ Goodfriend et al. ${ }^{57,58}$ showed a relationship between plasma aldosterone concentration and the amount of visceral fat, which was independent of renin. Accordingly, non-classical adrenal stimuli for aldosterone production had been reported, including oxidized products of linoleic acid ${ }^{59}$ and as-yet-unidentified potent mineralocorticoid-releasing factors secreted by adipocytes. ${ }^{60}$

Recent clinical evidence supports the intimate relationship between aldosterone and metabolic syndrome. Two cross-sectional clinical studies of African descent have shown that plasma aldosterone concentration is independently associated with metabolic syndrome. ${ }^{61,62}$ The $\mathrm{C}$ allele of the $-344 \mathrm{C} / \mathrm{T}$ variant in the promoter of the aldosterone synthase (CYP11B2) gene, which is associated with hyperaldosteronemia, was shown to increase susceptibility to metabolic syndrome in European men. ${ }^{42}$ Fallo et al. ${ }^{63}$ observed that patients with primary aldosteronism had a higher incidence of metabolic syndrome than those with essential hypertension (41.1 vs. $29.6 \% ; P<0.05)$. Furthermore, prospective studies of the Framingham Offspring Study participants indicated that individuals with higher circulating aldosterone levels have increased risk of developing hypertension and metabolic syndrome. ${ }^{64,65}$

Epidemiological studies have shown that low birth weight (intrauterine growth retardation) is related to the occurrence of metabolic syndrome in later life ('fetal programming' hypothesis). ${ }^{46}$ The risk of developing metabolic syndrome of men whose birth weight was $\leq 2.95 \mathrm{~kg}$ was more than 10 times greater than that of men whose birth weight was $>4.31 \mathrm{~kg}$. Aldosterone as well as glucocorticoid is suggested to be involved in the mechanisms, possibly because of the activation of the hypothalamus-pituitary-adrenal axis. ${ }^{66}$

Aldosterone excess has also been reported in several animal models of obesity and metabolic syndrome. For example, obese, heart failureprone SHHF/Mcc-fa cp is documented to have a higher plasma aldosterone level compared with $+/+$ control $(209.4 \pm 14.3$ vs. $\left.107.0 \pm 17.0 \mathrm{ngl}^{-1} ; P<0.05\right) .{ }^{67}$ de Paula et al ${ }^{68}$ showed that aldosterone has a critical role in the pathogenesis of hypertension in dietinduced obesity by mediating glomerular hyperfiltration and sodium retention. High fat diet caused body weight gain $(+53 \%)$ and $\mathrm{BP}$ elevation $(+16 \pm 3 \mathrm{~mm} \mathrm{Hg})$ in dogs, which were associated with increased plasma aldosterone concentration (from $31 \pm 7$ to $\left.58 \pm 18 \mathrm{ngl}^{-1}\right)$, glomerular filtration rate $(+38 \pm 6 \%)$ and cumulative $\mathrm{Na}$ balance $(+472 \pm 110 \mathrm{mEq})$. These changes were efficiently attenuated by eplerenone treatment despite a similar body weight gain.

Urinary aldosterone excretion is reported to be elevated in $d b / d b$ mice, an experimental model of obesity-associated type 2 diabetes mellitus that has a non-functional leptin receptor, compared with their control db/+ mice $\left(0.24 \pm 0.02\right.$ vs. $0.09 \pm 0.02 \mathrm{ng} \mathrm{mg}^{-1}$ creatinine; $P<0.05) .{ }^{69}$ In accordance with this, the expression of the aldosterone effector kinase, Sgk1, is increased in the kidney of this model..$^{70}$ Hyperaldosteronism in $d b / d b$ mice might be attributable, at least in part, to C1q TNF-related protein 1 (CTRP1). This $32-\mathrm{kDa}$ protein is expressed at a high level in the adipose tissues of obese $d b / d b$ mice and Zucker diabetic fatty $(f a / f a)$ rats, ${ }^{71}$ and has the ability to stimulate aldosterone secretion in the adrenal cortical cell line, H295R. ${ }^{72}$ Aldosterone, in turn, may contribute to adipokine abnormalities in $d b / d b$ mice, because the MR antagonist, eplerenone, corrected the obesity-related adipokine changes, such as increased TNF- $\alpha$, monocyte chemoattractant protein (MCP)-1 and plasminogen activator inhibitor (PAI)-1, and decreased adiponectin and PPAR- $\gamma \cdot{ }^{69}$ Supporting this, recent works have shown that MR is expressed in adipocytes and mediates mineralocorticoid and glucocorticoid effects on adipogenesis and white adipose tissue functions. ${ }^{69,73-75}$

ALDOSTERONE AS A MEDIATOR OF TARGET ORGAN DAMAGE Aldosterone has long been considered as a hormone that regulates electrolyte, fluid volume and BP homeostasis. ${ }^{76}$ Recently, however, a paradigm shift has occurred in the field of aldosterone research. ${ }^{77,78}$ 
Emerging evidence has shown aldosterone as an important mediator of cardiovascular and renal damage, in addition to its classic roles. ${ }^{78}$ Aldosterone acts on non-epithelial cells in the heart, vasculature, kidney and brain to cause tissue remodeling, inflammatory responses, fibrosis, induction of oxidative stress and endothelial dysfunction. ${ }^{79}$ These non-classical actions were highlighted by two large-scale randomized clinical trials, RALES and EPHESUS, ${ }^{80,81}$ in which treatment with low-dose MR antagonists, spironolactone and eplerenone, dramatically improved the outcomes of patients with severe congestive heart failure or left ventricular dysfunction after myocardial infarction taking the standard therapy including angiotensin-converting enzyme (ACE) inhibitors, ARBs, diuretics, $\beta$-blockers and digitalis. In the kidney, aldosterone injures glomerular visceral epithelial cells (podocytes), which form the final filtration barrier to plasma macromolecules in the glomerulus, leading to proteinuria and ultimately to glomerulosclerosis. ${ }^{82}$ Aldosterone also triggers proinflammatory responses and perivascular and interstitial fibrosis in the kidney. ${ }^{83,84}$

Historically, it was already shown in the 1940s (even before the isolation of aldosterone and MR!) that the stimulation of MR causes glomerulosclerosis and cardiac fibrosis. For example, Hans Selye is an advocator of 'stress theory (general adaptation syndrome)', in which he discovered the role of glucocorticoids in non-specific adaptation response to stressors. During the process of establishing this theory, he carried out a lot of experiments and found that the administration of desoxy (11-deoxy) corticosterone acetate (DOCA), the first synthetic steroid (which stimulates MR), to rats induces inflammatory and fibrotic changes in the heart and kidney. He described unilateral nephrectomy and salt loading as important conditioning factors. $\mathrm{He}$ considered that these phenotypes are due to mineralocorticoid actions of DOCA. Furthermore, he postulated a hypothesis that glucocorticoids have 'anti-'inflammatory actions as adaptation to stress, whereas mineralocorticoids may have 'pro-'inflammatory effects. $^{85}$ Since then, the uninephrectomized DOCA/salt rat has been frequently used as a model of hypertensive renal damage. However, the amount of endogenous deoxycorticosterone, a precursor of aldosterone, is extremely small, except for special conditions, such as patients with congenital adrenocorticosteroid synthase deficiency. Half a century later, it was shown that aldosterone, the physiological mineralocorticoid in our body, provokes proteinuria, inflammatory and fibrotic lesions in the heart and kidney. ${ }^{83,86}$ The pathogenetic role for aldosterone in CVD and CKD has been widely recognized after the publication of the epoch-making results of 'RALES' and 'EPHESUS'.

\section{ANTIPROTEINURIC EFFECTS OF MR ANTAGONISTS}

Clinical and experimental studies have shown that MR antagonists effectively ameliorate proteinuria in patients or in animal models of hypertension, diabetes mellitus and CKD. ${ }^{78,19,87-94}$

For example, White et al. ${ }^{87}$ compared the anti-albuminuric effect of eplerenone with the Ca blocker, amlodipine, in older patients with systolic hypertension. After 24 weeks of therapy, eplerenone reduced albuminuria to a greater extent than did amlodipine $(-52$ vs. $-10 \%$; $P=0.04$ ) in patients with microalbuminuria at baseline, although their hypotensive effects were comparable. Williams et al. compared the efficacy of eplerenone and enalapril in patients with stage 1 or stage 2 hypertension. After 12 months, the extent of BP reduction was similar between the two groups, whereas eplerenone was superior to enalapril in reducing albuminuria in patients who had an elevated value at baseline $(-62$ vs. $-26 \% ; P=0.01)$. These clinical studies implicate that proteinuria in these hypertensive patients is, at least in part, dependent on the aldosterone/MR system (beyond BP effect).
Mineralocorticoid receptor antagonists are supposed to be effective in patients who experience 'aldosterone breakthrough. ${ }^{95}$ When we administer ACE inhibitors or ARBs to patients, plasma aldosterone levels decrease at first. However, over the long term, the initially decreased aldosterone increases again in patients with 'aldosterone breakthrough.' The incidence reported ranges from 10\% over 6 months to $53 \%$ over 1 year. Sato et al. ${ }^{90}$ reported that after 40 weeks of ACE inhibitor therapy in patients with diabetic nephropathy, urinary albumin excretion was markedly higher among those who experienced aldosterone breakthrough than among those who did not. Horita et al. ${ }^{96}$ found similar results in patients with IgA (immunoglobulin A) nephropathy. A prospective randomized open-label study by Bianchi et al. ${ }^{92}$ showed that in CKD patients already treated with ACE inhibitors and/or ARBs, the addition of spironolactone reduced proteinuria and retarded the decrease in estimated glomerular filtration rate after 1 year of therapy.

\section{METABOLIC SYNDROME AND CKD: ROLE OF THE ALDOSTERONE/MR SYSTEM}

Chronic kidney disease is becoming another urgent public health problem worldwide. Even minor renal dysfunction is shown to be a significant risk factor for CVD. Epidemiological studies have shown that metabolic syndrome is an important modifiable risk factor for CKD. ${ }^{34,97-99}$ However, the mechanism linking metabolic syndrome to CKD has not been clearly elucidated. It cannot be solely attributable to the additive effects of individual components, such as hypertension and diabetes mellitus, ${ }^{97}$ and some unifying underlying mechanism has been suggested. We examined the role of aldosterone/MR signaling in this process, using spontaneously hypertensive rats (SHR)/NDmcr-cp (SHR/cp, obese SHR) as a rat model of metabolic syndrome. ${ }^{16}$ This rat is a derivative of SHR with $c p$ mutation in the leptin receptor gene, ${ }^{100}$ and it manifested a clustering of obesity, hypertension, hyperinsulinemia and hypertriglyceridemia.

Proteinuria is a central symptom of CKD. Obese SHR/cp developed marked proteinuria in an age-dependent manner. By contrast, urinary protein excretion remained low in non-obese SHR despite a similar BP level. Proteinuria in SHR/cp was accompanied by podocyte injury, as indicated by the attenuation of the normal podocyte marker nephrin, induction of the injured podocyte marker, desmin, and foot process effacement under electron microscopic analysis. These findings suggest that podocyte injury underlies the etiology of proteinuria in SHR/cp.

It is noted that the serum aldosterone level was higher in obese $\mathrm{SHR} / \mathrm{cp}$ than in non-obese SHR, and that there was a positive correlation between circulating aldosterone concentration and proteinuria. Expression of Sgk1, a downstream effector of aldosterone, was upregulated in the whole kidney and in the glomerular fraction of SHR/cp, supporting the causative role of aldosterone/MR activation. Indeed, the selective MR antagonist, eplerenone, effectively reduced proteinuria in $\mathrm{SHR} / \mathrm{cp}$. In parallel, eplerenone improved podocyte injury in SHR/cp, as shown by the changes in nephrin and desmin expressions. These data suggest that the aldosterone-provoked podocyte injury has a pivotal role in the pathogenesis of proteinuria in $\mathrm{SHR} / \mathrm{cp}$. We propose that adipocyte-derived aldosterone-releasing factors (ARFs), although still unidentified, may account for aldosterone elevation and the resultant target organ complication in SHR/cp. ${ }^{16,101}$

\section{SALT ACCELERATES TARGET ORGAN DAMAGE IN SHR/CP THROUGH MR ACTIVATION}

Recent clinical studies have shown the increased salt sensitivity of BP and target organ injury in patients with obesity and metabolic 

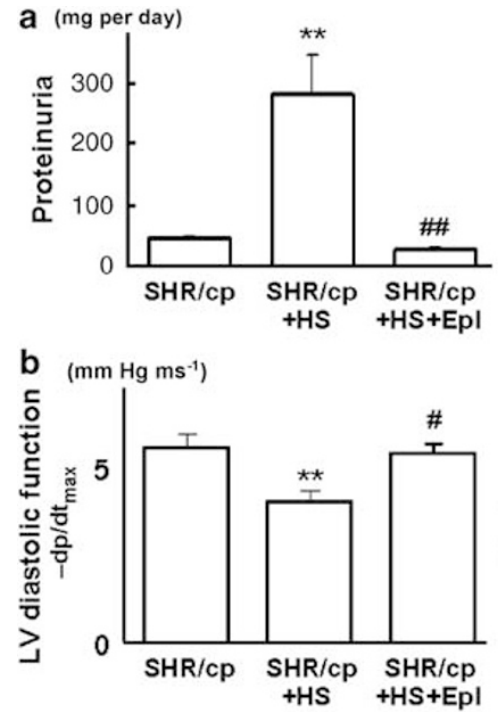

c

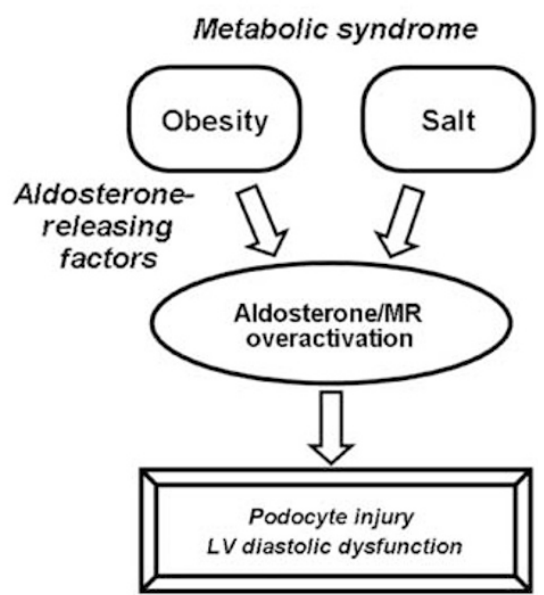

Figure 2 (a) Proteinuria of spontaneously hypertensive rats (SHR)/cp fed a normal diet (SHR/cp), SHR/cp fed a high-salt diet (SHR/cp+HS) and SHR/cp+HS treated with the mineralocorticoid receptor (MR) antagonist, eplerenone (SHR/cp+HS+Epl). ${ }^{17}$ (b) Left ventricular diastolic function was evaluated as $-\mathrm{dp} /$ $\mathrm{dt}_{\max }$ by direct LV pressure monitoring through cardiac catheterization. ${ }^{18}$ (c) Schematic representation of our hypothesis that obesity and salt, two cardinal features of a modern, civilized society, cause inappropriate activation of the aldosterone/MR system, leading to renal and cardiac injuries. ${ }^{* *} P<0.01$ vs. $\mathrm{SHR} / \mathrm{cp} ;{ }^{\#} P<0.05$ vs. SHR/cp+HS; ${ }^{\#} P<0.01$ vs. SHR/cp+HS.

syndrome. ${ }^{34-36,38}$ For example, Verhave et al. ${ }^{36}$ showed that higher sodium intake increases urinary albumin excretion in overweight individuals but not in non-overweight people. However, the mechanisms have not been clearly elucidated. Therefore, we examined the effects of salt loading on the nephropathy of SHR/cp. ${ }^{17}$

High-salt diet markedly enhanced proteinuria in $S H R / c p$ (Figure 2a). Interestingly, the MR antagonist, eplerenone, perfectly inhibited the salt-induced exacerbation, suggesting the involvement of the aldosterone/MR cascade. Similarly, salt worsened glomerular podocyte impairment and renal histopathological findings (glomerulosclerosis, tubulointerstitial injury and renal arteriolar lesions), which were completely mitigated by eplerenone. Although salt loading suppressed circulating renin and aldosterone, it paradoxically activated renal MR signaling, as shown by increased MR in the nuclear fraction, induction of aldosterone effector kinase Sgk1 and upregulation of putative mediators of aldosterone-evoked organ damage, such as transforming growth factor- $\beta 1, \mathrm{PAI}-1$ and MCP- 1 in the kidney of salt-loaded SHR/cp. Eplerenone completely inhibited these MRdependent cascades. The paradoxical MR activation might be attributable in part to adipocyte-derived ARFs. Although the RAS-regulated aldosterone generation is counterbalanced by salt, our preliminary data suggest that aldosterone production by ARFs lacks negative feedback regulation in response to high salt intake. As a result, the suppression of the circulating aldosterone level might be less than expected, causing inappropriately high aldosterone for the amount of salt intake.

Cross-talk between the kidney and the cardiovascular system has recently become a major topic. ${ }^{102}$ We examined whether the same mechanism can be extrapolated to the pathogenesis of cardiac injury in our rats. ${ }^{18}$ Cardiac catheterization and Doppler echocardiographic analysis indicated that the left ventricular diastolic function was impaired in salt-loaded SHR/cp, which was fully recovered by eplerenone (Figure 2b).

These findings corroborate our hypothesis that obesity and salt, two cardinal features of a modern, civilized society, cause MR activation, leading ultimately to CVD and CKD (Figure 2c).

\section{NOVEL MECHANISM OF LIGAND-INDEPENDENT MR ACTIVATION AND ITS IMPLICATION IN CKD}

So far, we have described MR activation and target organ injury in high aldosterone models. Recently, we and others ${ }^{19,20,103}$ reported that MR activation could also have a crucial role in target organ damage even in normal or low aldosterone states. Dahl salt-hypertensive rats develop podocyte injury, proteinuria, glomerulosclerosis and cardiac failure under a high-salt diet. Although the circulating aldosterone level was low, MR activation was noted in the target organ, and eplerenone dramatically retarded the progression of renal and cardiac diseases. These findings raise the possibility that molecules other than aldosterone may activate MR.

To date, little is known about the mechanisms of ligand-independent MR activation. ${ }^{104,105}$ MR belongs to the nuclear receptor superfamily acting as a transcription factor; on ligand binding, the ligandreceptor complex translocates into the nucleus, where it dimerizes and interacts with the mineralocorticoid response element in the promoter region of the target genes to activate gene transcription. From this point of view, the activity of MR should be modulated by multiple factors other than the ligand level. As for the other steroid receptors, intracellular signaling molecules were shown to influence the receptor activity. ${ }^{106-109}$ We identified a small G protein, Racl, as a potent activator of MR. ${ }^{21}$

To address the possibility that the Rho family GTPases can modulate MR activity, we first carried out in vitro transfection assays in human embryonic kidney 293 cells. In luciferase reporter assays, MR-dependent transcriptional activity was upregulated in response to aldosterone. Overexpression of constitutively active (CA)-Rac1, not wild-type or dominant-negative Racl, potentiated this response further. CA-Racl also increased the luciferase activity even without aldosterone. We further assessed the nuclear translocation of green fluorescence protein (GFP)-tagged MR. Without aldosterone, GFP fluorescence was distributed mainly in the cytoplasm; on activation by aldosterone, MR-GFP was promptly targeted to the nucleus. Quantitative analysis showed that CA-Racl substantially increased the amount of nuclear MR-GFP, both in the absence and presence of 


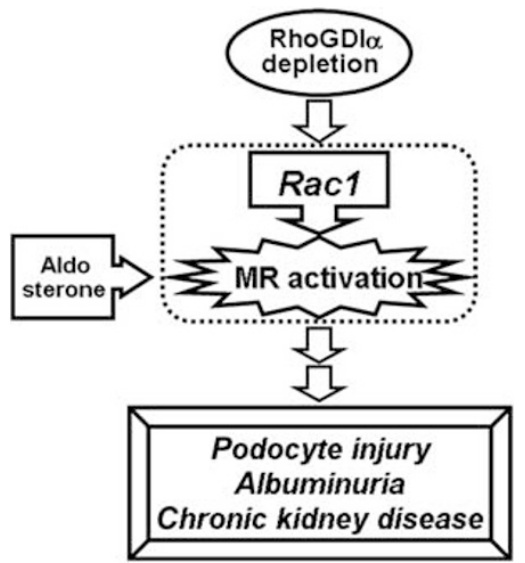

Figure 3 Mechanisms of renal injury in Rho guanosine diphosphate (GDP) dissociation inhibitor (RhoGDI) $\alpha$ knockout (KO) mice. Depletion of GDI $\alpha$ causes Rac1 activation in the kidney, which mediates aldosteroneindependent mineralocorticoid receptor (MR) activation and the resultant podocyte injury, albuminuria and chronic kidney disease.

aldosterone. These results indicate that CA-Racl causes MR activation.

Thereafter, we investigated whether this 'Racl-evoked MR activation' might contribute to the pathogenesis of renal injury in vivo, using the Rho guanosine diphosphate (GDP) dissociation inhibitor (RhoG$\mathrm{DI}) \alpha$ knockout (KO) mice, ${ }^{110}$ a kidney-specific Racl activation model. At 12 weeks of age, the $\mathrm{KO}$ mice showed massive albuminuria, glomerular podocyte damage and focal and segmental glomerulosclerosis. Treatment with the Rac-specific inhibitor, NSC23766, ${ }^{111,112}$ substantially ameliorated the renal impairment concomitantly with repression of Racl activity. We examined the aldosterone/MR status in this model. Although the serum aldosterone concentration and BP were not increased, the amount of MR in the nuclear fraction and the expression of Sgk1, a downstream target of MR, were upregulated in the kidneys of $\mathrm{KO}$ mice, suggesting an aldosterone-independent MR activation. Therefore, we treated the KO mice with MR antagonist. Eplerenone dramatically ameliorated albuminuria, renal histopathological changes, podocyte injury and induction of MR-related injury mediators, such as MCP-1 and PAI-1. Furthermore, NSC23766 also suppressed MR activation, as assessed by the expressions of Sgk1, PAI1 and MCP-1. These results indicate that the Rac1-mediated MR activation has a central role in the renal phenotype of RhoGDI $\alpha$ KO mice (Figure 3). Traditionally, Racl GTPase is known to have diverse biological functions, such as actin cytoskeletal organization, cell migration and generation of oxidative stress, as components of NADPH oxidase. ${ }^{113}$ On the other hand, Racl was recently shown to be indispensable for the nuclear localization of $\beta$-catenin in canonical Wnt signaling ${ }^{114}$ and of STAT5 in cytokine signaling, ${ }^{115}$ in addition to our finding of nuclear MR translocation, highlighting novel roles for Rac1 in the nucleocytoplasmic shuttling of transcription factors.

As RhoGDI $\alpha \mathrm{KO}$ mice constitute a rather artificial model, we evaluated the involvement of the Rac1-MR pathway in a more common CKD model. We administered NSC23766 to the abovementioned Dahl salt-sensitive rats, which elicited MR activation in the kidney despite a low serum aldosterone level. Salt triggers BP elevation and glomerular damage in this model. Racl was activated in the kidneys of salt-loaded Dahl salt-sensitive rats, and the administration of NSC23766 significantly suppressed MR activation, proteinuria and glomerulosclerosis. These findings imply that Racl activation might contribute, at least in part, to the non-aldosterone-mediated MR activation in this model.

Altogether, we identified Racl as a ligand-independent activator of MR. This alternative pathway of MR activation actually has a significant role in the progression of renal injury in some $\mathrm{CKD}$ models, implicating Racl as a novel therapeutic target for CKD. We have preliminary data indicating that Racl is activated in response to various stimuli relevant to metabolic syndrome (data not shown). Thus, MR can be activated in the kidney of metabolic syndrome by several different pathways, both aldosterone dependently (through ARFs) and independently (through Rac1), and mediates renal injury.

\section{VERTEBRATE EVOLUTION AND THE ALDOSTERONE/MR SYSTEM}

Finally, we describe evolutional perspectives on the aldosterone/MR system. Aldosterone, a principal regulator of sodium reabsorption in the kidney, is postulated to have had a crucial role in the phylogenetic transition from aquatic fishes to land-living tetrapods. ${ }^{116}$ As a means to sustaining life on land with little salinity, terrestrial animals used aldosterone/MR to recapitulate the sea water environment within the body. Indeed, aquatic fishes do not possess aldosterone, whereas tetrapods acquire it. On the other hand, MR, the receptor, had already been present long before aldosterone evolved. During aquatic life without aldosterone, MR served as a receptor for other ligands and conveyed its own function. The probability of simultaneous acquisition of both ligand and receptor during evolution would be very low. In the case of aldosterone, the hormone 'exploited' other ligands' receptor MR and compelled it to a new role in electrolyte homeostasis, which eventually became the main function of MR.

When humans first appeared, the amount of available salt was limited, and salt was one of the most precious commodities. During a long period of salt scarcity, people with stronger 'salt retention' genes had a significant survival advantage. In our modern, industrialized societies, we now have plenty of salt, and an energy imbalance causes a pandemic of obesity. The cultural changes have far outpaced any possible genetic adaptations, and obesity and salt synergistically cause inappropriate activation of the aldosterone/MR system, according to our animal data. Individuals who have genes for enhanced 'saltretentive' activity are especially predisposed to diseases of civilization, such as salt-sensitive hypertension, CVD and CKD, when faced with the contemporary environment. Target organ damage by aldosterone might be a manifestation of the exaggerated original function of MR during the aquatic life.

\section{PERSPECTIVES}

We have summarized the literature on obesity hypertension/metabolic syndrome and aldosterone/MR. We have shown that SHR/cp, a metabolic syndrome model, is susceptible to renal and cardiac injuries, especially when the animal is fed a high-salt diet. Inappropriate activation of the aldosterone/MR system underlies target organ diseases. We have shown that MR can be activated by several different pathways, both aldosterone dependently (through ARFs) and independently (through Racl, for example). These findings support our hypothesis that obesity and salt, two central features of the modern society, cause MR overactivation, leading to CVD and CKD.

Future studies are necessary to identify the clinical conditions in which Racl is overactivated and the Rac inhibitor is effective, and to determine the intrarenal localization of activated Racl. For this purpose, clinical studies using a renal biopsy specimen of CKD patients are under investigation. We expect that ARFs and Racl can be novel targets of therapy for metabolic syndrome and CKD. We also 
have to establish handy diagnostic tools to evaluate the tissue MR activation state, because circulating aldosterone concentration does not necessarily reflect MR activity in the target organ. Finally, we have to accumulate clinical evidence to prove the efficacy of MR blockade in patients with obesity and metabolic syndrome by largescale clinical trials.

1 Mann CC. Public health. Provocative study says obesity may reduce US life expectancy. Science 2005; 307: 1716-1717.

2 Flier JS. Obesity wars: molecular progress confronts an expanding epidemic. Cell 2004; 116: 337-350.

3 Grundy SM, Brewer Jr HB, Cleeman JI, Smith Jr SC, Lenfant C. Definition of metabolic syndrome: Report of the National Heart, Lung, and Blood Institute/American Heart Association conference on scientific issues related to definition. Circulation 2004; 109: 433-438.

4 Despres JP, Lemieux I. Abdominal obesity and metabolic syndrome. Nature 2006; 444: 881-887.

5 Shulman AI, Mangelsdorf DJ. Retinoid $x$ receptor heterodimers in the metabolic syndrome. N Engl J Med 2005; 353: 604-615.

6 Tobin JF, Freedman LP. Nuclear receptors as drug targets in metabolic diseases: new approaches to therapy. Trends Endocrinol Metab 2006; 17: 284-290.

7 Evans RM, Barish GD, Wang YX. PPARs and the complex journey to obesity. Nat Med 2004; 10: 355-361.

8 Mangelsdorf DJ, Thummel C, Beato M, Herrlich P, Schutz G, Umesono K, Blumberg B, Kastner P, Mark M, Chambon P, Evans RM. The nuclear receptor superfamily: the second decade. Cell 1995; 83: 835-839.

9 Heine PA, Taylor JA, Iwamoto GA, Lubahn DB, Cooke PS. Increased adipose tissue in male and female estrogen receptor-alpha knockout mice. Proc Natl Acad Sci USA 2000; 97: 12729-12734.

10 Yanase T, Fan W, Kyoya K, Min L, Takayanagi R, Kato S, Nawata H. Androgens and metabolic syndrome: lessons from androgen receptor knock out (ARKO) mice. J Steroid Biochem Mol Biol 2008; 109: 254-257.

11 Masuzaki H, Paterson J, Shinyama H, Morton NM, Mullins JJ, Seckl JR, Flier JS. A transgenic model of visceral obesity and the metabolic syndrome. Science 2001; 294: 2166-2170.

12 He W, Barak Y, Hevener A, Olson P, Liao D, Le J, Nelson M, Ong E, Olefsky JM, Evans RM. Adipose-specific peroxisome proliferator-activated receptor gamma knockout causes insulin resistance in fat and liver but not in muscle. Proc Natl Acad Sci USA 2003; 100: 15712-15717.

13 Lee CH, Olson P, Hevener A, Mehl I, Chong LW, Olefsky JM, Gonzalez FJ, Ham J, Kang $\mathrm{H}$, Peters JM, Evans RM. PPARdelta regulates glucose metabolism and insulin sensitivity. Proc Natl Acad Sci USA 2006; 103: 3444-3449.

14 Sharma AM, Engeli S. The role of renin-angiotensin system blockade in the management of hypertension associated with the cardiometabolic syndrome. J Cardiometab Syndr 2006; 1: 29-35.

15 Boustany CM, Bharadwaj K, Daugherty A, Brown DR, Randall DC, Cassis LA Activation of the systemic and adipose renin-angiotensin system in rats with dietinduced obesity and hypertension. Am J Physiol Regul Integr Comp Physiol 2004; 287: R943-R949.

16 Nagase M, Yoshida S, Shibata S, Nagase T, Gotoda T, Ando K, Fujita T. Enhanced aldosterone signaling in the early nephropathy of rats with metabolic syndrome: possible contribution of fat-derived factors. J Am Soc Nephrol 2006; 17: 34383446.

17 Nagase M, Matsui H, Shibata S, Gotoda T, Fujita T. Salt-induced nephropathy in obese spontaneously hypertensive rats via paradoxical activation of the mineralocorticoid receptor: role of oxidative stress. Hypertension 2007; 50: 877-883.

18 Matsui H, Ando K, Kawarazaki H, Nagae A, Fujita M, Shimosawa T, Nagase M, Fujita T. Salt excess causes left ventricular diastolic dysfunction in rats with metabolic disorder. Hypertension 2008; 52: 287-294.

19 Nagase M, Shibata S, Yoshida S, Nagase T, Gotoda T, Fujita T. Podocyte injury underlies the glomerulopathy of Dahl salt-hypertensive rats and is reversed by aldosterone blocker. Hypertension 2006; 47: 1084-1093.

20 Nagata K, Obata K, Xu J, Ichihara S, Noda A, Kimata H, Kato T, Izawa H, Murohara T, Yokota M. Mineralocorticoid receptor antagonism attenuates cardiac hypertrophy and failure in low-aldosterone hypertensive rats. Hypertension 2006; 47: 656-664.

21 Shibata S, Nagase M, Yoshida S, Kawarazaki W, Kurihara H, Tanaka H, Miyoshi J, Takai Y, Fujita T. Modification of mineralocorticoid receptor function by Rac1 GTPase: implication in proteinuric kidney disease. Nat Med 2008; 14: 1370-1376.

22 Zennaro MC, Le Menuet D, Viengchareun S, Walker F, Ricquier D, Lombes M. Hibernoma development in transgenic mice identifies brown adipose tissue as a novel target of aldosterone action. J Clin Invest 1998; 101: 1254-1260.

23 Viengchareun S, Penfornis P, Zennaro MC, Lombes M. Mineralocorticoid and glucocorticoid receptors inhibit UCP expression and function in brown adipocytes. Am J Physiol Endocrinol Metab 2001; 280: E640-E649.

24 Le Menuet D, Isnard R, Bichara M, Viengchareun S, Muffat-Joly M, Walker F, Zennaro MC, Lombes M. Alteration of cardiac and renal functions in transgenic mice overexpressing human mineralocorticoid receptor. J Biol Chem 2001; 276: 38911-38920.
25 Newton-Cheh C, Johnson T, Gateva V, Tobin MD, Bochud M, Coin L, Najjar SS, Zhao JH, Heath SC, Eyheramendy S, Papadakis K, Voight BF, Scott LJ, Zhang F, Farrall M, Tanaka T, Wallace C, Chambers JC, Khaw KT, Nilsson P, van der Harst P, Polidoro S, Grobbee DE, Onland-Moret NC, Bots ML, Wain LV, Elliott KS, Teumer A, Luan J, Lucas G, Kuusisto J, Burton PR, Hadley D, McArdle WL, Brown M, Dominiczak A, Newhouse SJ, Samani NJ, Webster J, Zeggini E, Beckmann JS, Bergmann S, Lim N, Song K, Vollenweider P, Waeber G, Waterworth DM, Yuan X, Groop L, Orho-Melander M, Allione A, Di Gregorio A, Guarrera S, Panico S, Ricceri F, Romanazzi V, Sacerdote C, Vineis P, Barroso I, Sandhu MS, Luben RN, Crawford GJ, Jousilahti P, Perola M, Boehnke M, Bonnycastle LL, Collins FS, Jackson AU, Mohlke KL, Stringham HM, Valle TT, Willer CJ, Bergman RN, Morken MA, Doring A, Gieger C, Illig T, Meitinger T, Org E, Pfeufer A, Wichmann HE, Kathiresan S, Marrugat J, O'Donnell CJ, Schwartz SM, Siscovick DS, Subirana I, Freimer NB, Hartikainen AL, McCarthy MI, O'Reilly PF, Peltonen L, Pouta $A$, de Jong PE, Snieder H, van Gilst WH, Clarke R, Goel A, Hamsten A, Peden JF, Seedorf U, Syvanen AC, Tognoni G, Lakatta EG, Sanna S, Scheet P, Schlessinger D, Scuteri A, Dorr M, Ernst F, Felix SB, Homuth G, Lorbeer R, Reffelmann T, Rettig R, Volker U, Galan P, Gut IG, Hercberg S, Lathrop GM, Zelenika D, Deloukas P, Soranzo N, Williams FM, Zhai G, Salomaa V, Laakso M, Elosua R, Forouhi NG, Volzke H, Uiterwaal CS, van der Schouw YT, Numans ME, Matullo G, Navis G, Berglund G, Bingham SA, Kooner JS, Connell JM, Bandinelli S, Ferrucci L, Watkins H, Spector TD, Tuomilehto J, Altshuler D, Strachan DP, Laan M, Meneton P, Wareham NJ, Uda M, Jarvelin MR, Mooser V, Melander O, Loos RJ, Elliott P, Abecasis GR, Caulfield M, Munroe PB. Genome-wide association study identifies eight loci associated with blood pressure. Nat Genet 2009; 41: 666-676.

26 Levy D, Ehret GB, Rice K, Verwoert GC, Launer LJ, Dehghan A, Glazer NL, Morrison $A C$, Johnson $A D$, Aspelund $T$, Aulchenko $Y$, Lumley $T$, Kottgen A, Vasan RS, Rivadeneira F, Eiriksdottir G, Guo X, Arking DE, Mitchell GF, Mattace-Raso FU, Smith AV, Taylor K, Scharpf RB, Hwang SJ, Sijbrands EJ, Bis J, Harris TB, Ganesh SK, O'Donnell CJ, Hofman A, Rotter JI, Coresh J, Benjamin EJ, Uitterlinden AG, Heiss G, Fox CS, Witteman JC, Boerwinkle E, Wang TJ, Gudnason V, Larson MG, Chakravarti A, Psaty BM, van Duijn CM. Genome-wide association study of blood pressure and hypertension. Nat Genet 2009; 41: 677-687.

27 Stamler R, Stamler J, Riedlinger WF, Algera G, Roberts RH. Weight and blood pressure. Findings in hypertension screening of 1 million Americans. JAMA 1978; 240: 1607-1610.

28 Garrison RJ, Kannel WB, Stokes III J, Castelli WP. Incidence and precursors of hypertension in young adults: the Framingham Offspring Study. Prev Med 1987; 16: 235-251.

29 Vasan RS, Larson MG, Leip EP, Kannel WB, Levy D. Assessment of frequency of progression to hypertension in non-hypertensive participants in the Framingham Heart Study: a cohort study. Lancet 2001; 358: 1682-1686.

30 Hayashi T, Boyko EJ, Leonetti DL, McNeely MJ, Newell-Morris L, Kahn SE, Fujimoto WY. Visceral adiposity is an independent predictor of incident hypertension in Japanese Americans. Ann Intern Med 2004; 140: 992-1000.

31 Higgins M, Kannel W, Garrison R, Pinsky J, Stokes III J. Hazards of obesity-the Framingham experience. Acta Med Scand Supp/ 1988; 723: 23-36.

32 Reaven GM, Lithell H, Landsberg L. Hypertension and associated metabolic abnormalities-the role of insulin resistance and the sympathoadrenal system. $N$ Engl J Med 1996; 334: 374-381.

33 Lakka HM, Laaksonen DE, Lakka TA, Niskanen LK, Kumpusalo E, Tuomilehto J, Salonen JT. The metabolic syndrome and total and cardiovascular disease mortality in middle-aged men. JAMA 2002; 288: 2709-2716.

34 Chen J, Muntner P, Hamm LL, Jones DW, Batuman V, Fonseca V, Whelton PK, He J. The metabolic syndrome and chronic kidney disease in US adults. Ann Intern Med 2004; 140: 167-174.

35 He J, Ogden LG, Vupputuri S, Bazzano LA, Loria C, Whelton PK. Dietary sodium intake and subsequent risk of cardiovascular disease in overweight adults. JAMA 1999; 282: 2027-2034.

36 Verhave JC, Hillege HL, Burgerhof JG, Janssen WM, Gansevoort RT, Navis GJ, de Zeeuw D, de Jong PE. Sodium intake affects urinary albumin excretion especially in overweight subjects. J Intern Med 2004; 256: 324-330.

37 Chen J, Gu D, Huang J, Rao DC, Jaquish CE, Hixson JE, Chen CS, Chen J, Lu F, Hu D, Rice T, Kelly TN, Hamm LL, Whelton PK, He J. Metabolic syndrome and salt sensitivity of blood pressure in non-diabetic people in China: a dietary intervention study. Lancet 2009; 373: 829-835.

38 Uzu T, Kimura G, Yamauchi A, Kanasaki M, Isshiki K, Araki S, Sugiomoto T, Nishio Y, Maegawa H, Koya D, Haneda M, Kashiwagi A. Enhanced sodium sensitivity and disturbed circadian rhythm of blood pressure in essential hypertension. $J$ Hypertens 2006; 24: 1627-1632.

39 Pausova Z, Gaudet D, Gossard F, Bernard M, Kaldunski ML, Jomphe M, Tremblay J, Hudson TJ, Bouchard G, Kotchen TA, Cowley AW, Hamet P. Genome-wide scan for linkage to obesity-associated hypertension in French Canadians. Hypertension 2005; 46: 1280-1285.

40 Pausova Z, Deslauriers B, Gaudet D, Tremblay J, Kotchen TA, Larochelle P, Cowley AW, Hamet P. Role of tumor necrosis factor-alpha gene locus in obesity and obesityassociated hypertension in French Canadians. Hypertension 2000; 36: 14-19.

41 Rosmond $\mathrm{R}$. The glucocorticoid receptor gene and its association to metabolic syndrome. Obes Res 2002; 10: 1078-1086.

42 Russo P, Lauria F, Loguercio M, Barba G, Arnout J, Cappuccio FP, de Lorgeril M, Donati MB, lacoviello L, Krogh V, van Dongen M, Siani A. 344C/T Variant in the promoter of the aldosterone synthase gene (CYP11B2) is associated with metabolic syndrome in men. Am J Hypertens 2007; 20: 218-222. 
43 Lang F, Bohmer C, Palmada M, Seebohm G, Strutz-Seebohm N, Vallon V. Patho)physiological significance of the serum- and glucocorticoid-inducible kinase isoforms. Physiol Rev 2006; 86: 1151-1178.

44 Neel JV. Diabetes mellitus: a 'thrifty' genotype rendered detrimental by 'progress'? Am J Hum Genet 1962; 14: 353-362.

45 Sharma AM. The thrifty-genotype hypothesis and its implications for the study of complex genetic disorders in man. J Mol Med 1998; 76: 568-571.

46 Barker DJ, Hales CN, Fall CH, Osmond C, Phipps K, Clark PM. Type 2 (non-insulindependent) diabetes mellitus, hypertension and hyperlipidaemia (syndrome $\mathrm{X}$ ): relation to reduced fetal growth. Diabetologia 1993; 36: 62-67.

47 Guyton AC. Blood pressure control-special role of the kidneys and body fluids. Science 1991; 252: 1813-1816.

48 Hall JE, Kuo JJ, da Silva AA, de Paula RB, Liu J, Tallam L. Obesity-associated hypertension and kidney disease. Curr Opin Nephrol Hypertens 2003; 12: 195-200.

49 Coatmellec-Taglioni G, Ribiere C. Factors that influence the risk of hypertension in obese individuals. Curr Opin Nephrol Hypertens 2003; 12: 305-308.

50 Rahmouni K, Correia ML, Haynes WG, Mark AL. Obesity-associated hypertension: new insights into mechanisms. Hypertension 2005; 45: 9-14.

51 Mark AL, Correia ML, Rahmouni K, Haynes WG. Selective leptin resistance: a new concept in leptin physiology with cardiovascular implications. J Hypertens 2002; 20 : 1245-1250.

52 Masuzaki H, Yamamoto H, Kenyon CJ, Elmquist JK, Morton NM, Paterson JM, Shinyama H, Sharp MG, Fleming S, Mullins JJ, Seckl JR, Flier JS. Transgenic amplification of glucocorticoid action in adipose tissue causes high blood pressure in mice. J Clin Invest 2003; 112: 83-90.

53 Zheng Y, Yamada H, Sakamoto K, Horita S, Kunimi M, Endo Y, Li Y, Tobe K, Terauchi Y, Kadowaki T, Seki G, Fujita T. Roles of insulin receptor substrates in insulin-induced stimulation of renal proximal bicarbonate absorption. J Am Soc Nephrol 2005; 16: 2288-2295.

54 Tuck ML, Sowers J, Dornfeld L, Kledzik G, Maxwell M. The effect of weight reduction on blood pressure, plasma renin activity, and plasma aldosterone levels in obese patients. N Engl J Med 1981; 304: 930-933.

55 Engeli S, Bohnke J, Gorzelniak K, Janke J, Schling P, Bader M, Luft FC, Sharma AM. Weight loss and the renin-angiotensin-aldosterone system. Hypertension 2005; 45: 356-362.

56 Ruano M, Silvestre V, Castro R, Garcia-Lescun MC, Rodriguez A, Marco A, GarciaBlanch G. Morbid obesity, hypertensive disease and the renin-angiotensin-aldosterone axis. Obes Surg 2005; 15: 670-676

57 Goodfriend TL, Egan BM, Kelley DE. Aldosterone in obesity. Endocr Res 1998; 24: 789-796.

58 Goodfriend TL, Kelley DE, Goodpaster BH, Winters SJ. Visceral obesity and insulin resistance are associated with plasma aldosterone levels in women. Obes Res 1999; 7: 355-362.

59 Goodfriend TL, Ball DL, Egan BM, Campbell WB, Nithipatikom K. Epoxy-keto derivative of linoleic acid stimulates aldosterone secretion. Hypertension 2004; 43 : 358-363.

60 Ehrhart-Bornstein M, Lamounier-Zepter V, Schraven A, Langenbach J, Willenberg HS, Barthel A, Hauner H, McCann SM, Scherbaum WA, Bornstein SR. Human adipocytes secrete mineralocorticoid-releasing factors. Proc Natl Acad Sci USA 2003; 100: 14211-14216.

61 Bochud M, Nussberger J, Bovet P, Maillard MR, Elston RC, Paccaud F, Shamlaye C, Burnier M. Plasma aldosterone is independently associated with the metabolic syndrome. Hypertension 2006; 48: 239-245.

62 Kidambi S, Kotchen JM, Grim CE, Raff H, Mao J, Singh RJ, Kotchen TA. Association of adrenal steroids with hypertension and the metabolic syndrome in blacks. Hypertension 2007; 49: 704-711.

63 Fallo F, Veglio F, Bertello C, Sonino N, Della Mea P, Ermani M, Rabbia F, Federspil G, Mulatero P. Prevalence and characteristics of the metabolic syndrome in primary aldosteronism. J Clin Endocrinol Metab 2006; 91: 454-459.

64 Vasan RS, Evans JC, Larson MG, Wilson PW, Meigs JB, Rifai N, Benjamin EJ, Levy D. Serum aldosterone and the incidence of hypertension in nonhypertensive persons. $N$ Engl J Med 2004; 351: 33-41.

65 Ingelsson E, Pencina MJ, Tofler GH, Benjamin EJ, Lanier KJ, Jacques PF, Fox CS, Meigs JB, Levy D, Larson MG, Selhub J, D'Agostino Sr RB, Wang TJ, Vasan RS. Multimarker approach to evaluate the incidence of the metabolic syndrome and longitudinal changes in metabolic risk factors: the Framingham Offspring Study. Circulation 2007; 116: 984-992.

66 Reynolds RM, Walker BR, Phillips DI, Dennison EM, Fraser R, Mackenzie SM, Davies E, Connell JM. Programming of Hypertension. Associations of Plasma Aldosterone in Adult Men and Women With Birthweight, Cortisol, and Blood Pressure. Hypertension 2009; 53: 932-936.

67 Radin MJ, Holycross BJ, Hoepf TM, McCune SA. Increased salt sensitivity secondary to leptin resistance in SHHF rats is mediated by endothelin. Mol Cell Biochem 2003; 242: 57-63.

68 de Paula RB, da Silva AA, Hall JE. Aldosterone antagonism attenuates obesityinduced hypertension and glomerular hyperfiltration. Hypertension 2004; 43: 41-47.

69 Guo C, Ricchiuti V, Lian BQ, Yao TM, Coutinho P, Romero JR, Li J, Williams GH, Adler GK. Mineralocorticoid receptor blockade reverses obesity-related changes in expression of adiponectin, peroxisome proliferator-activated receptor-gamma, and proinflammatory adipokines. Circulation 2008; 117: 2253-2261.

70 Kumar JM, Brooks DP, Olson BA, Laping NJ. Sgk, a putative serine/threonine kinase, is differentially expressed in the kidney of diabetic mice and humans. $J$ Am Soc Nephrol 1999; 10: 2488-2494.
71 Kim KY, Kim HY, Kim JH, Lee CH, Kim DH, Lee YH, Han SH, Lim JS, Cho DH, Lee MS, Yoon S, Kim KI, Yoon DY, Yang Y. Tumor necrosis factor-alpha and interleukin1 beta increases CTRP1 expression in adipose tissue. FEBS Lett 2006; 580: 39533960.

72 Jeon JH, Kim KY, Kim JH, Baek A, Cho H, Lee YH, Kim JW, Kim D, Han SH, Lim JS, Kim KI, Yoon do Y, Kim SH, Oh GT, Kim E, Yang Y. A novel adipokine CTRP1 stimulates aldosterone production. FASEB J 2008; 22: 1502-1511.

73 Caprio M, Feve B, Claes A, Viengchareun S, Lombes M, Zennaro MC. Pivotal role of the mineralocorticoid receptor in corticosteroid-induced adipogenesis. FASEB J 2007; 21: 2185-2194.

74 Kraus D, Jager J, Meier B, Fasshauer M, Klein J. Aldosterone inhibits uncoupling protein-1, induces insulin resistance, and stimulates proinflammatory adipokines in adipocytes. Horm Metab Res 2005; 37: 455-459.

75 Rondinone CM, Rodbard D, Baker ME. Aldosterone stimulated differentiation of mouse 3T3-L1 cells into adipocytes. Endocrinology 1993; 132: 2421-2426.

76 Williams JS, Williams GH. 50th anniversary of aldosterone. J Clin Endocrinol Metab 2003; 88: 2364-2372.

77 Hostetter TH, Ibrahim HN. Aldosterone in chronic kidney and cardiac disease. J Am Soc Nephrol 2003; 14: 2395-2401.

78 Epstein M. Aldosterone blockade: an emerging strategy for abrogating progressive renal disease. Am J Med 2006; 119: 912-919.

79 Leopold JA, Dam A, Maron BA, Scribner AW, Liao R, Handy DE, Stanton RC, Pitt B, Loscalzo J. Aldosterone impairs vascular reactivity by decreasing glucose-6-phosphate dehydrogenase activity. Nat Med 2007; 13: 189-197.

80 Pitt B, Zannad F, Remme WJ, Cody R, Castaigne A, Perez A, Palensky J, Wittes J. The effect of spironolactone on morbidity and mortality in patients with severe heart failure. Randomized Aldactone Evaluation Study Investigators. N Engl J Med 1999; 341: 709-717.

81 Pitt B, Remme W, Zannad F, Neaton J, Martinez F, Roniker B, Bittman R, Hurley S, Kleiman J, Gatlin M. Eplerenone, a selective aldosterone blocker, in patients with left ventricular dysfunction after myocardial infarction. N Engl J Med 2003; 348: 13091321.

82 Shibata S, Nagase M, Yoshida S, Kawachi H, Fujita T. Podocyte as the target for aldosterone: roles of oxidative stress and Sgk1. Hypertension 2007; 49: 355-364.

83 Blasi ER, Rocha R, Rudolph AE, Blomme EA, Polly ML, McMahon EG. Aldosterone/ salt induces renal inflammation and fibrosis in hypertensive rats. Kidney Int 2003; 63: 1791-1800.

84 Nishiyama A, Yao L, Nagai Y, Miyata K, Yoshizumi M, Kagami S, Kondo S, Kiyomoto H, Shokoji T, Kimura S, Kohno M, Abe Y. Possible contributions of reactive oxygen species and mitogen-activated protein kinase to renal injury in aldosterone/saltinduced hypertensive rats. Hypertension 2004; 43: 841-848.

85 Selye H. Anticortisol action of aldosterone. Science 1955; 121: 368-369.

86 Brilla CG, Weber KT. Mineralocorticoid excess, dietary sodium, and myocardial fibrosis. J Lab Clin Med 1992; 120: 893-901.

87 White WB, Duprez D, St Hillaire R, Krause S, Roniker B, Kuse-Hamilton J, Weber MA. Effects of the selective aldosterone blocker eplerenone versus the calcium antagonist amlodipine in systolic hypertension. Hypertension 2003; 41: 1021-1026.

88 Williams GH, Burgess E, Kolloch RE, Ruilope LM, Niegowska J, Kipnes MS, Roniker B, Patrick JL, Krause SL. Efficacy of eplerenone versus enalapril as monotherapy in systemic hypertension. Am J Cardiol 2004; 93: 990-996.

89 Epstein M, Williams GH, Weinberger M, Lewin A, Krause S, Mukherjee R, Patni R, Beckerman B. Selective aldosterone blockade with eplerenone reduces albuminuria in patients with type 2 diabetes. Clin J Am Soc Nephrol 2006; 1: 940-951.

90 Sato A, Hayashi K, Naruse M, Saruta T. Effectiveness of aldosterone blockade in patients with diabetic nephropathy. Hypertension 2003; 41: 64-68.

91 Chrysostomou A, Pedagogos E, MacGregor L, Becker GJ. Double-blind, placebocontrolled study on the effect of the aldosterone receptor antagonist spironolactone in patients who have persistent proteinuria and are on long-term angiotensin-converting enzyme inhibitor therapy, with or without an angiotensin II receptor blocker. Clin J Am Soc Nephrol 2006; 1: 256-262.

92 Bianchi S, Bigazzi R, Campese VM. Long-term effects of spironolactone on proteinuria and kidney function in patients with chronic kidney disease. Kidney Int 2006; 70: 2116-2123.

93 Han SY, Kim CH, Kim HS, Jee YH, Song HK, Lee MH, Han KH, Kim HK, Kang YS, Han JY, Kim YS, Cha DR. Spironolactone prevents diabetic nephropathy through an antiinflammatory mechanism in type 2 diabetic rats. J Am Soc Nephrol 2006; 17: 1362 1372.

94 Aldigier JC, Kanjanbuch T, Ma LJ, Brown NJ, Fogo AB. Regression of existing glomerulosclerosis by inhibition of aldosterone. J Am Soc Nephrol 2005; 16: 3306-3314.

95 Bomback AS, Klemmer PJ. The incidence and implications of aldosterone breakthrough. Nat Clin Pract Nephrol 2007; 3: 486-492.

96 Horita Y, Taura K, Taguchi T, Furusu A, Kohno S. Aldosterone breakthrough during therapy with angiotensin-converting enzyme inhibitors and angiotensin II receptor blockers in proteinuric patients with immunoglobulin A nephropathy. Nephrology (Carlton) 2006; 11: 462-466.

97 Kurella M, Lo JC, Chertow GM. Metabolic syndrome and the risk for chronic kidney disease among nondiabetic adults. J Am Soc Nephrol 2005; 16: 2134-2140.

98 Ninomiya T, Kiyohara Y, Kubo M, Yonemoto K, Tanizaki Y, Doi Y, Hirakata H, lida M. Metabolic syndrome and CKD in a general Japanese population: the Hisayama Study. Am J Kidney Dis 2006; 48: 383-391.

99 Tanaka H, Shiohira Y, Uezu Y, Higa A, Iseki K. Metabolic syndrome and chronic kidney disease in Okinawa, Japan. Kidney Int 2006; 69: 369-374. 
100 Takaya K, Ogawa Y, Hiraoka J, Hosoda K, Yamori Y, Nakao K, Koletsky RJ. Nonsense mutation of leptin receptor in the obese spontaneously hypertensive Koletsky rat. Nat Genet 1996; 14: 130-131.

101 Nagase M, Fujita T. Aldosterone and glomerular podocyte injury. Clin Exp Nephrol 2008; 12: 233-242.

102 Ritz E, McClellan WM. Overview: increased cardiovascular risk in patients with mino renal dysfunction: an emerging issue with far-reaching consequences. J Am Soc Nephrol 2004; 15: 513-516.

103 Sato A, Saruta T. Aldosterone-induced organ damage: plasma aldosterone level and inappropriate salt status. Hypertens Res 2004; 27: 303-310.

104 Massaad C, Houard N, Lombes M, Barouki R. Modulation of human mineralocorticoid receptor function by protein kinase A. Mol Endocrinol 1999; 13: 57-65.

105 Yokota K, Shibata H, Kurihara I, Kobayashi S, Suda N, Murai-Takeda A, Saito I, Kitagawa $\mathrm{H}$, Kato $\mathrm{S}$, Saruta $\mathrm{T}$, Itoh $\mathrm{H}$. Coactivation of the $\mathrm{N}$-terminal transactivation of mineralocorticoid receptor by Ubc9. J Biol Chem 2007; 282: 1998-2010.

106 Kato S, Endoh H, Masuhiro Y, Kitamoto T, Uchiyama S, Sasaki H, Masushige S, Gotoh $Y$, Nishida E, Kawashima H, Metzger D, Chambon P. Activation of the estrogen receptor through phosphorylation by mitogen-activated protein kinase. Science 1995; 270: 1491-1494.

107 Yanagisawa J, Yanagi Y, Masuhiro Y, Suzawa M, Watanabe M, Kashiwagi K, Toriyabe T, Kawabata M, Miyazono K, Kato S. Convergence of transforming growth factor-beta and vitamin D signaling pathways on SMAD transcriptional coactivators. Science 1999; 283: 1317-1321.

108 Su LF, Knoblauch R, Garabedian MJ. Rho GTPases as modulators of the estrogen receptor transcriptional response. J Biol Chem 2001; 276: 3231-3237.
109 Kino T, Souvatzoglou E, Charmandari E, Ichijo T, Driggers P, Mayers C, Alatsatianos A, Manoli I, Westphal H, Chrousos GP, Segars JH. Rho family Guanine nucleotide exchange factor Brx couples extracellular signals to the glucocorticoid signaling system. J Biol Chem 2006; 281: 9118-9126.

110 Togawa A, Miyoshi J, Ishizaki H, Tanaka M, Takakura A, Nishioka H, Yoshida H, Doi T, Mizoguchi A, Matsuura N, Niho Y, Nishimune Y, Nishikawa S, Takai Y. Progressive impairment of kidneys and reproductive organs in mice lacking Rho GDlalpha. Oncogene 1999; 18: 5373-5380.

111 Gao Y, Dickerson JB, Guo F, Zheng J, Zheng Y. Rational design and characterization of a Rac GTPase-specific small molecule inhibitor. Proc Natl Acad Sci USA 2004; 101: 7618-7623.

112 Cancelas JA, Lee AW, Prabhakar R, Stringer KF, Zheng Y, Williams DA. Rac GTPases differentially integrate signals regulating hematopoietic stem cell localization. Nat Med 2005; 11: 886-891.

113 Takai Y, Sasaki T, Matozaki T. Small GTP-binding proteins. Physiol Rev 2001; 81: 153-208.

114 Wu X, Tu X, Joeng KS, Hilton MJ, Williams DA, Long F. Rac1 activation controls nuclear localization of beta-catenin during canonical Wnt signaling. Cell 2008; 133: 340-353.

115 Kawashima T, Bao YC, Nomura Y, Moon Y, Tonozuka Y, Minoshima Y, Hatori T, Tsuchiya A, Kiyono M, Nosaka T, Nakajima H, Williams DA, Kitamura T. Rac1 and a GTPaseactivating protein, MgcRacGAP, are required for nuclear translocation of STAT transcription factors. J Cell Biol 2006; 175: 937-946.

116 Bridgham JT, Carroll SM, Thornton JW. Evolution of hormone-receptor complexity by molecular exploitation. Science 2006; 312: 97-101. 